UDC (07)621.7,621.8

DOI: $10.25140 / 2411-5363-2020-4(22)-48-56$

\author{
Peter Tuleja, Boris Jobbagy
}

\title{
MANIPULATION TASK REALISED BY THE VACUUM SUCTION CUP IMPLEMENTATION
}

Urgency of the research. The area covered by the article addresses both the technical and economic aspects of compressed air management, which is the most expensive type of energy used in the manufacturing sector. It is extremely urgent to save energy as it is, not excluding compressed air.

Target setting. The aim of the article is to give a comprehensive picture of the problems in solving one-sided gripping by the action of vacuum. It gives instructions on how to proceed with their removal, with the focus on the procedures for saving basic energy - compressed air.

Actual scientific researches and issues analysis. At present, great attention is paid to this area not only by users of applications using compressed air and vacuum, but also by manufacturers of technology working on these principles. Practically all large manufacturers of pneumatic components are dedicated to it.

Uninvestigated parts of general matters defining. The article does not pay attention to the production and treatment of compressed air, but only its consumption in the preparation of vacuum. Also, in the calculations, only the basic relationships are indicated, by which the experienced user will find a solution to their problem.

The research objective. The aim of the article is to present the results of research in the field and to indicate the possibilities of technical procedures for solving the application of vacuum gripping effectors using active vacuum suction cups.

The statement of basic materials. The material which became the article base consists of both general knowledge contained in the technical literature, as well as own analyzes of partial data summarized in the conclusions.

Conclusions. The conclusions resulting from the article offer instructions for solving a set of problems in the design of vacuum gripping effectors with suction cups.

Keywords: manipulation, manipulation task, compressed air, vacuum, suction cup, pneumatic circuit.

Fig.: 10. Table: 1. References: 5.

Introduction. Automated production is based on a number of handling tasks. Although manipulation is considered an unproductive component of production, but without it we cannot imagine production. Manipulated objects (semi-finished products, workpieces) are made of various materials and have many surface properties. These properties are often specific. Nevertheless, it is necessary to meet the basic condition of the handling task: the handling object $\left(\mathrm{O}_{\mathrm{M}}\right)$ must be unambiguously grasped and fixed by the means of the gripping means and guaranteed during the whole period of transport to the target position.

The means intended to fulfill the handling task is referred to as the gripping effector.

Gripping effector. The solution of its construction results from the application properties of the manipulation task. It consists in a suitable arrangement of various kinematic chains, which allow the transfer of forces from the used drive (pneumatic, hydraulic, electric) to the $\mathrm{O}_{\mathrm{M}}$. This creates the required gripping force.

This force can be applied to $\mathrm{O}_{M}$ in various ways [3]:

in the form of contact with $\mathrm{O}_{M}$ at two or more points;

in the form of contact with $\mathrm{O}_{\mathrm{M}}$ at one point relative to the fixed base (passive grip - without the action of the drive);

in the form of contact with $\mathrm{O}_{\mathrm{M}}$ at one point without additional support (one-sided gripping).

One-sided gripping with an active suction cup. One-sided gripping excludes the possibility of $\mathrm{O}_{M}$ support at some auxiliary point. The entire weight of the $\mathrm{O}_{M}$ is fixed only by the effect of the effector. Therefore, the force effects of this weight during the handling task must be thoroughly analyzed.

Each of the known methods of one-sided gripping [3] is based on a certain physical nature of the gripping force. In the case of gripping with an active suction cup, it is a vacuum. However, the contact force of the effector with $\mathrm{O}_{M}$ during handling is negatively affected by the weight of the $\mathrm{O}_{M}$ itself (static gravitational force, or tilting moments), as well as the forces resulting from the dynamic effects of the manipulator (manipulator, robot). The force balance on a static (stationary) suction cup is shown in Fig. 1. This is an ideal situation where the center of the suction cup (TCP) and the position of the center of gravity of the $\mathrm{O}_{M}\left(\mathrm{~T}_{\mathrm{OM}}\right)$ are identical. 


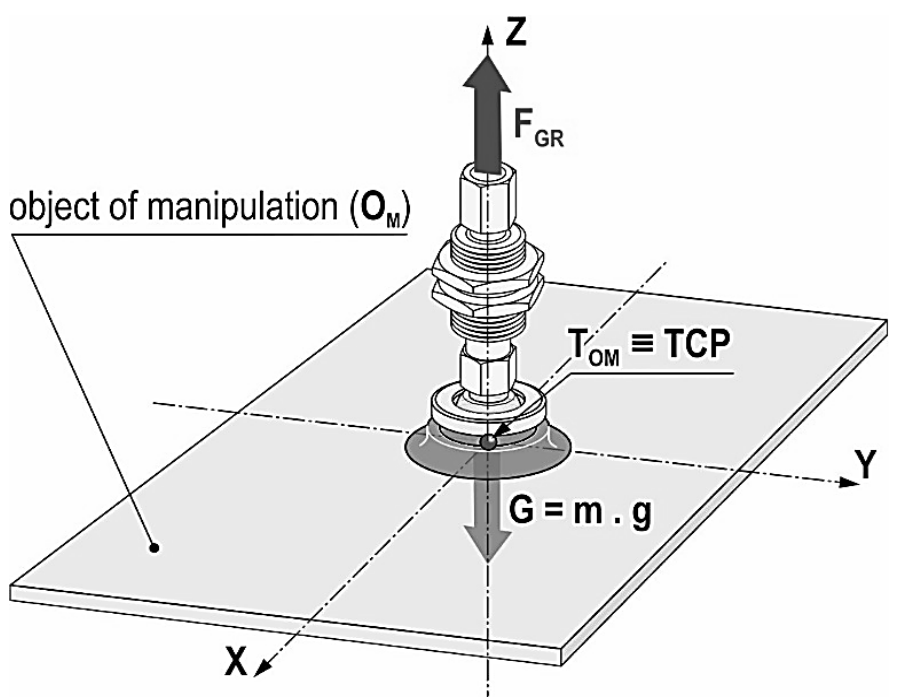

Fig. 1. Force ratios when gripping with a suction cup

The theoretical force of the suction cup is expressed by the relationship

$$
F_{T}=10^{-3} \cdot S_{e f} \cdot p_{v}
$$

where $S_{e f}$ is the effective area of the suction cup [mm $\left.{ }^{2}\right]$, Fig. 2, $p_{v}$ is the pressure value, expressed as the absolute value of the relative vacuum in $[\mathrm{kPa}]$. Thus, as can be seen from Fig. 2, the effective area of the suction cup will be calculated from the dimension $\mathrm{D}_{1 \mathrm{e}}$.

However, this value is not easy to determine in technical practice, therefore it is necessary to relate the gripping force of the suction cup to the effective area of the suction cup stated for a specific type of suction cup by the manufacturer. The contour diameter of an unloaded suction cup is usually considered to be the effective diameter and the difference from reality is neglected. Therefore, in the following relations, we will state the effective diameter of the suction cup only as the diameter of the suction cup $d[\mathrm{~mm}]$.

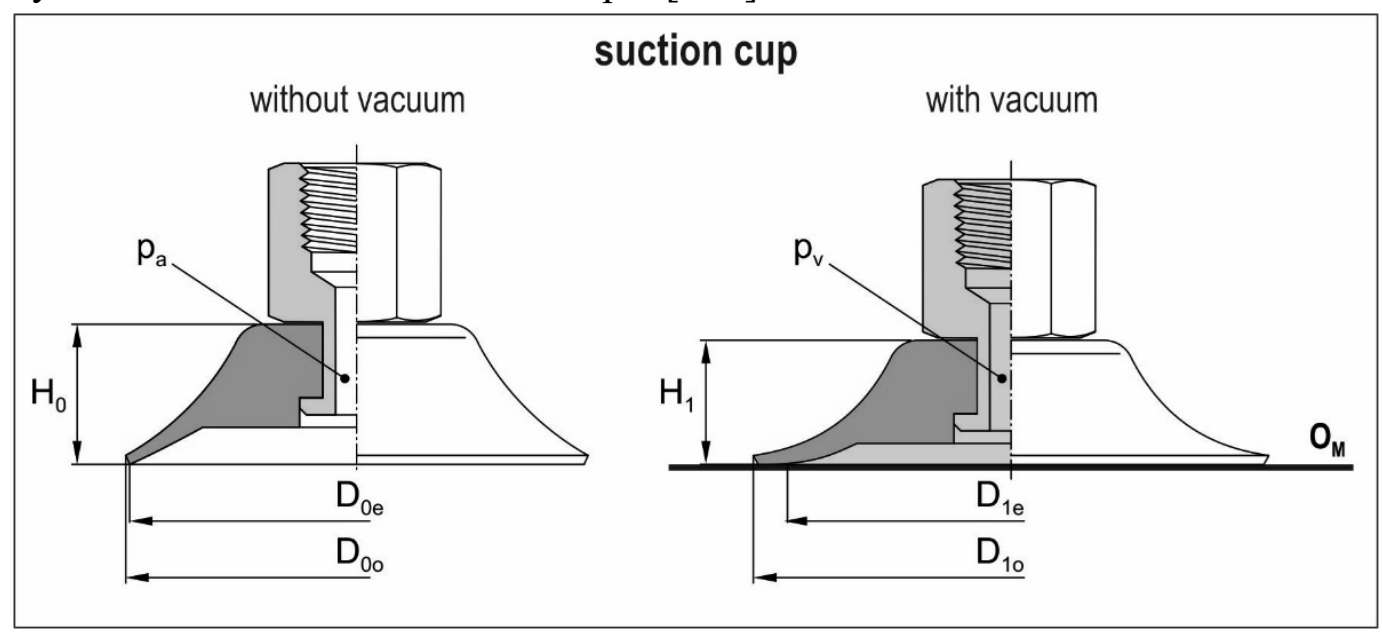

Fig. 2. Determination of the effective area of the suction cup

Then the relation for calculating the theoretical force of the suction cup will be

$$
F_{T}=10^{-3} \cdot \frac{\pi \cdot d^{2}}{4} \cdot p_{v} \quad[\mathrm{~N}]
$$

The effective (real) force of the $\mathrm{F}_{\mathrm{GR}}$ suction cup is then determined by the relationship

$$
F_{G R}=\frac{1}{t} \cdot F_{T}=\frac{10^{-3} \cdot \pi \cdot d^{2} \cdot p_{v}}{4 \cdot t} \quad[\mathrm{~N}]
$$

The coefficient $t$ is determined according to the real situation of the manipulation accelerations acting from Table: 
Dynamic conditions during suction cup handling [1]

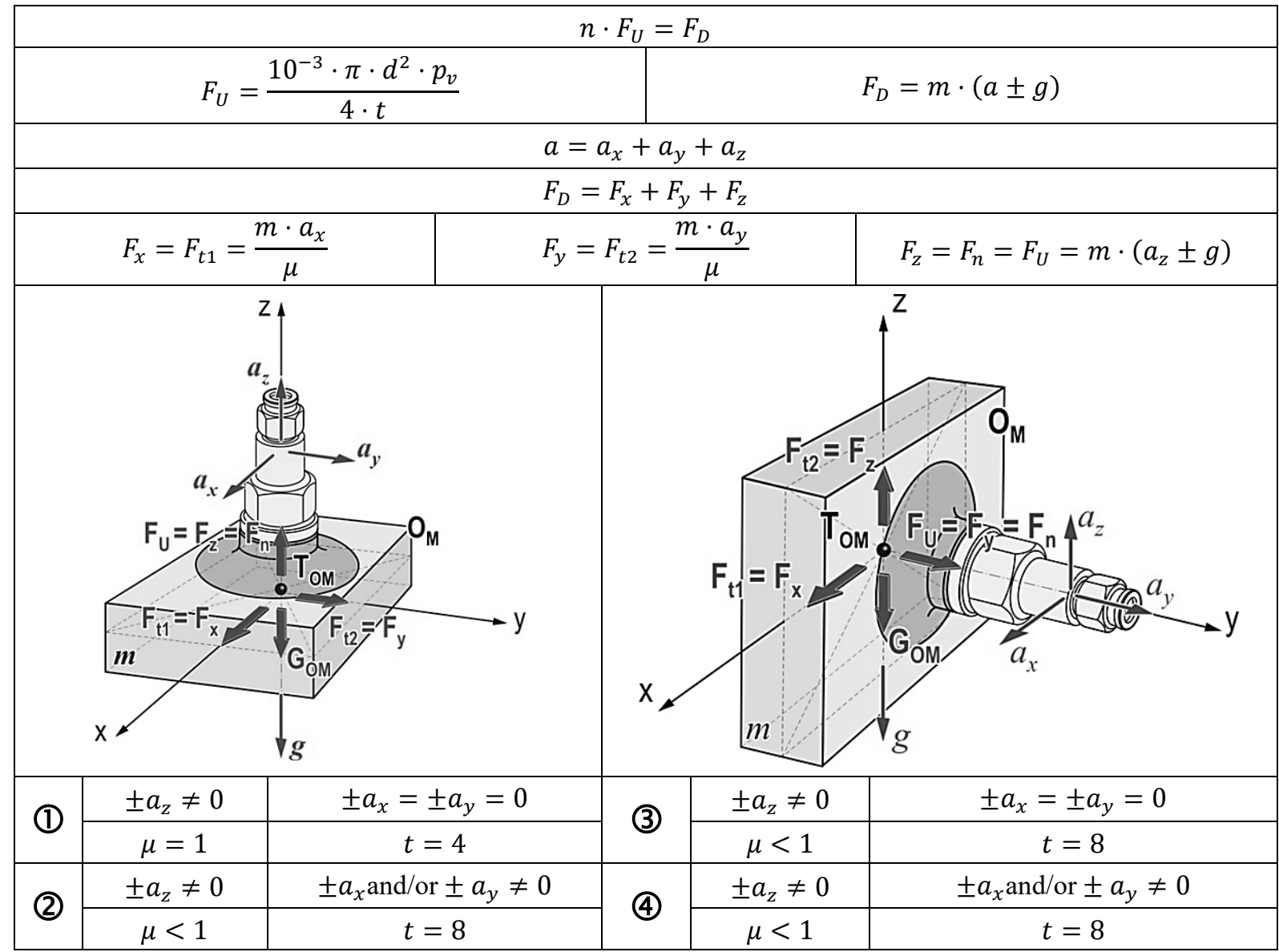

Creating sufficient gripping force on the suction cup means creating perfect contact of the suction cup with the $\mathrm{O}_{M}$ surface and generating a sufficiently high-quality vacuum under the suction cup. From relation (1) it is obvious that in addition to the quality of the vacuum under the suction cup, the size of the gripping force will also be determined by the diameter of the suction cup (its effective area).

It often happens that a vacuum generator is sought to increase the gripping force of the suction cup, which ensures a high value of vacuum quality.

Increasing the active area of the suction cup(s) is a much more gradual way. This means that, if circumstances allow, it is more advantageous to use more suction cups or a suction cup with a larger diameter than to spend money to generate a "super-quality" vacuum.

It is necessary to realize that the vacuum in the handling tasks is generated by jet generators ejectors much more often than by a vacuum pump.

However, this means that compressed air must be used to create a vacuum. Its consumption then determines the total cost of operating the device with suction cups.

If we look at the balance on the ejector, Fig. 3, we will realize a few basic rules for the use of vacuum:

the quality of the vacuum and the volume of the intake air do not increase proportionally and indefinitely with increasing pressure, Fig. 3a), 3c);

the air consumption per ejector increases in direct proportion to the increasing pressure, Fig. 3b);

the volume of the intake air is stopped only after reaching the maximum vacuum which the ejector is capable of, Fig. 3d). 
TECHNICAL SCIENCES AND TECHNOLOGIES

a)

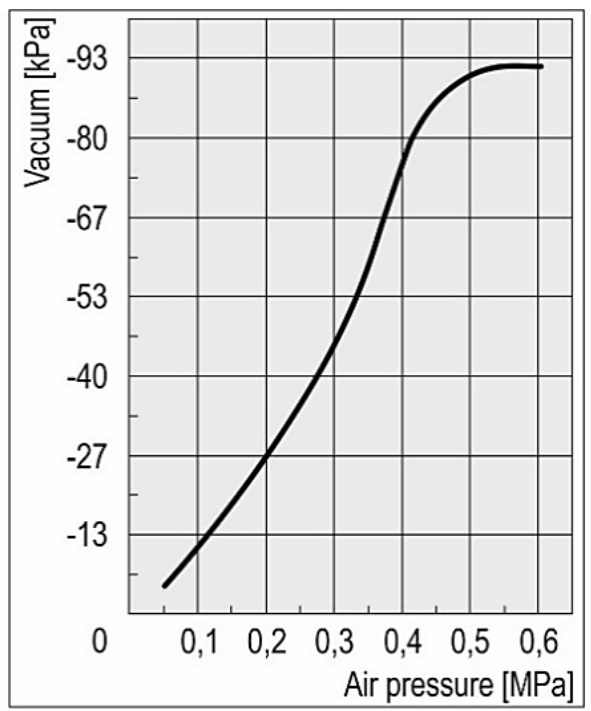

c)

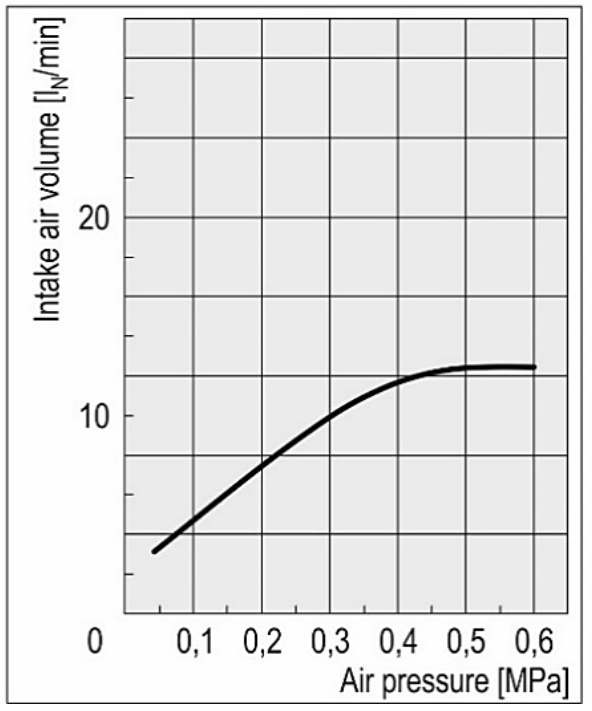

b)

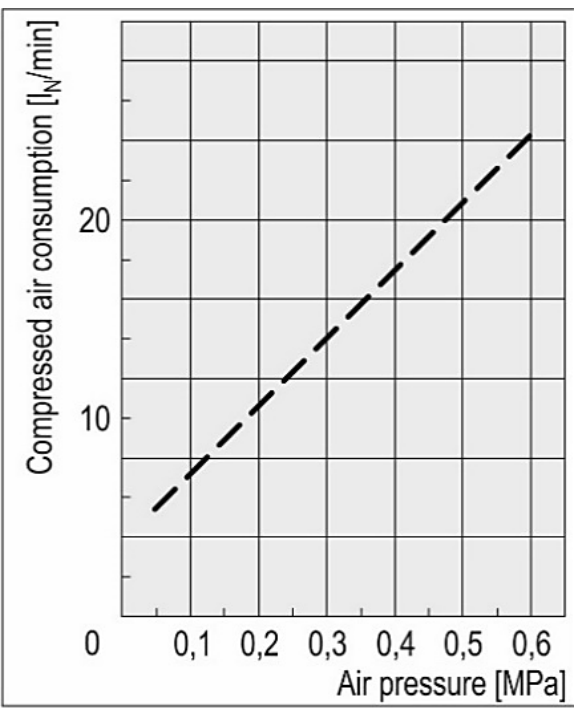

d)

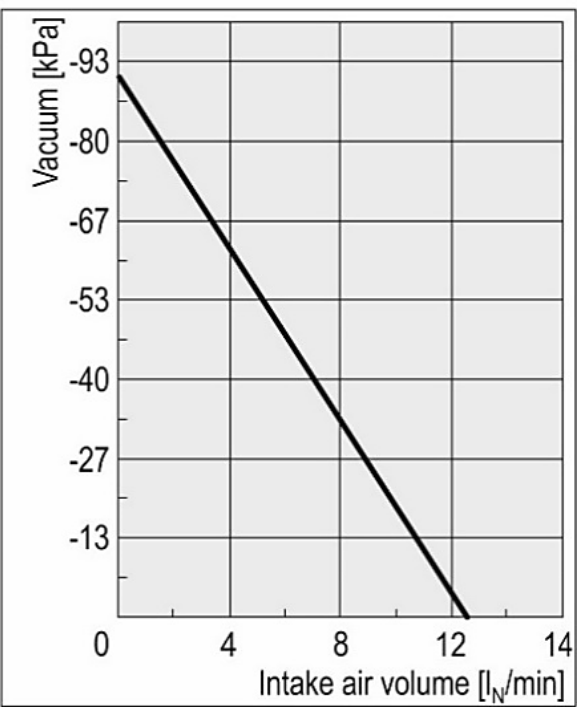

Fig. 3. Pressure and flow ratios on the ejector

Source: [4]; modified by the authors.

It is pointless to increase the pressure of the air entering the ejector above the level of 0.5-0.6 $\mathrm{MPa}$, as in the nozzle-diffuser system of the ejector the flow rate rises above a critical value (speed of sound in air), which causes the so-called "rupture" of the vacuum. The suction cup stops acting on $\mathrm{O}_{\mathrm{M}}$.

Also from course d) in Fig. 3, it is clear that the imperfectly sealed volume under the suction cup almost absolutely negates the value of the vacuum generated by the ejector. This must be kept in mind if we cannot ensure guaranteed occupancy of all suction cups, Fig. 4.

In cases where the occupancy guarantee is not possible, either due to a missing object, Fig. 4a) or displacement of the manipulation object, Fig. 4b), it is necessary to solve the situation in one of the ways shown in Fig. 5; variant a) represents the use of a non-return valve which is "deactivated" in the presence of an object, variant b) considers the use of a vacuum saving valve [4]. 


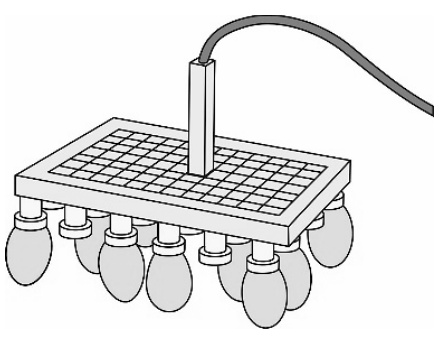

$a$

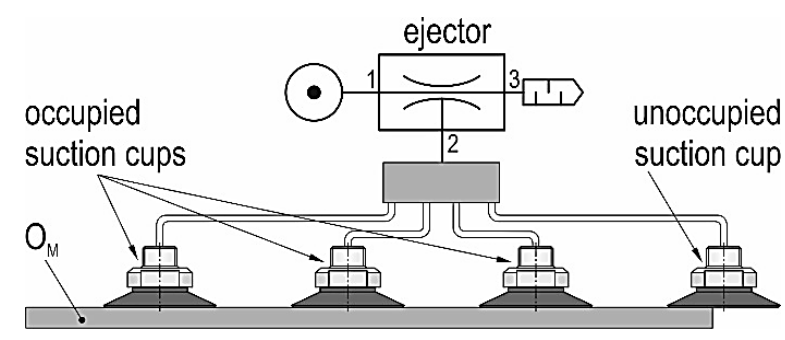

$b$

Fig. 4. Reasons for "vacancy" of the suction cup[1],[5]

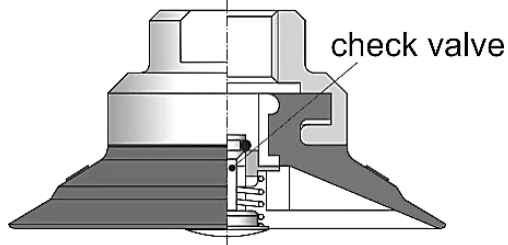

$a$
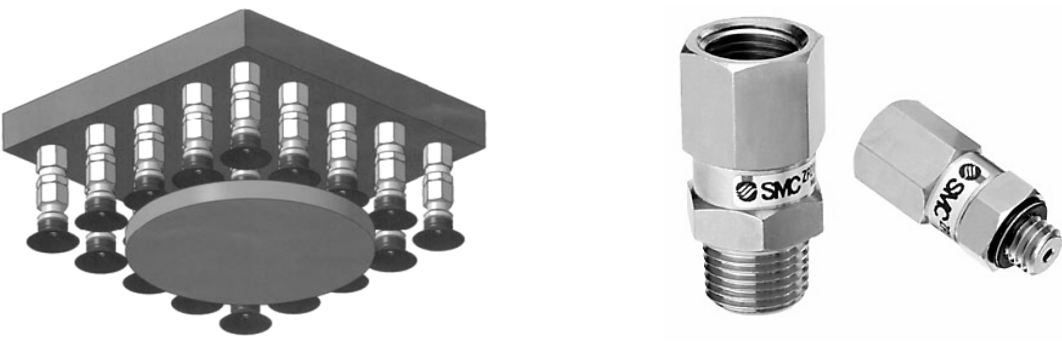

$b$

Fig. 5. Solution of "vacancy" of the suction cup [1; 4; 5]

Energy for vacuum production. As it was already mentioned, in order to create the gripping force of the suction cup, a vacuum under the suction cup sleeve is required, which at the moment of its generation must already have contact with the $\mathrm{O}_{M}$ surface by a suitable mechanism.

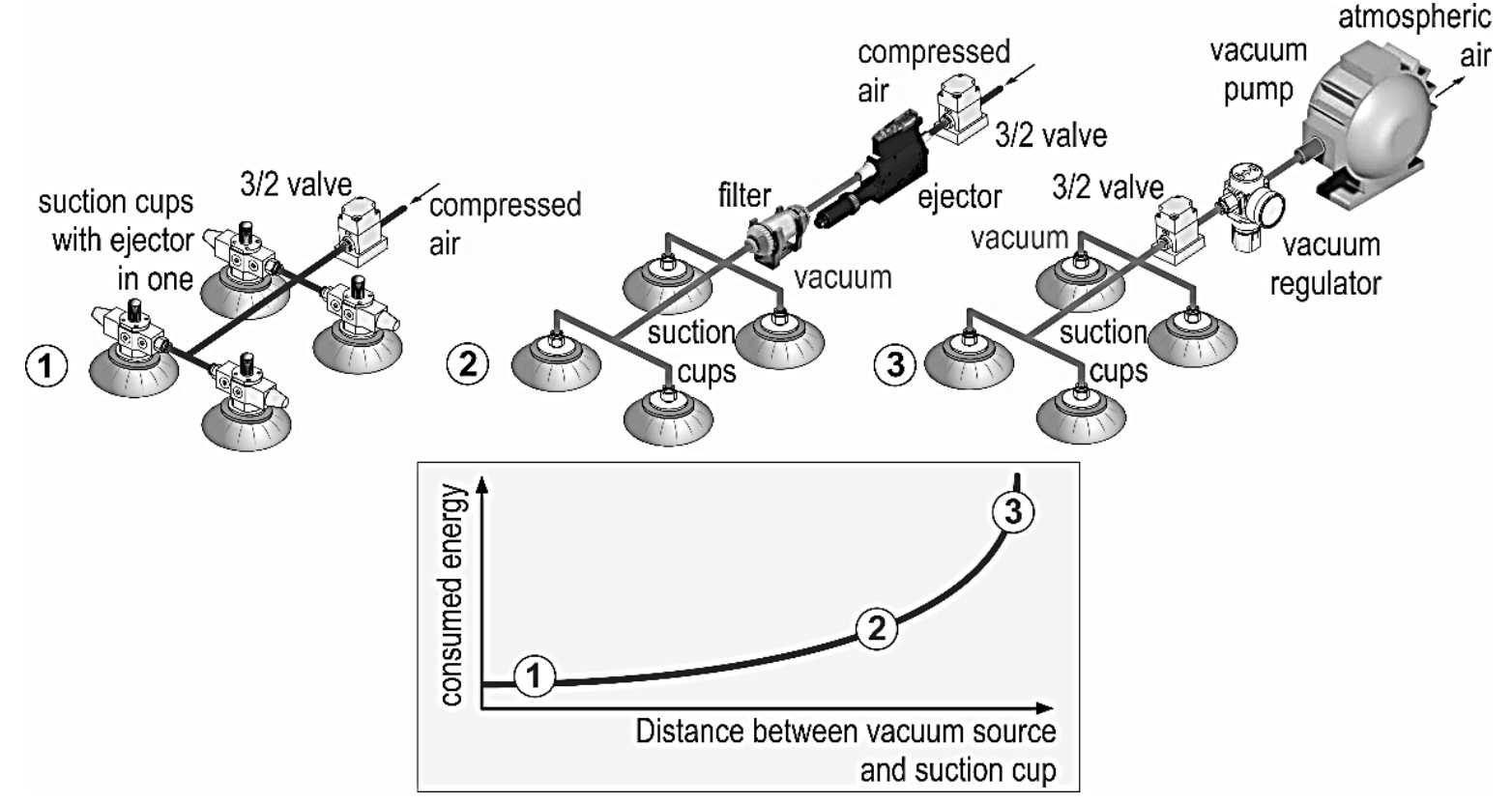

Fig. 6. Comparison of energy requirements for suction cup activation [5] modified 
We have also already stated that in manipulation tasks performed by robotic technology, the method of generating vacuum by a jet generator, so an ejector, is much more frequently used. This ensures a higher readiness and reaction time of the effector during the handling task, as the developer can be placed close enough to the suction cup and thus the loss of vacuum through the transmission system is eliminated (Fig. 6). Then only the compressed air distribution is needed (vacuum distribution does not have to be specially designed), it is even possible to eliminate the losses of its distribution using the ejector-suction cup combination. This reduces the energy requirements for operation, Fig. 6.

The volume of compressed air flowed directly depends on the pressure of the flowing air and the quality of the developed vacuum, Fig. 3.

From the diagram in Fig. 3a) it follows that the quality of the vacuum increases almost linearly only in the range of inlet pressures from $0.2 \mathrm{MPa}$ to $0.5 \mathrm{MPa}$. The effective value of the maximum inlet pressure is approximately at the level of $0.4 \mathrm{MPa}$. Even at this inlet air pressure, the value of the developed vacuum is at the level of about $-85 \mathrm{kPa}$, i.e. about $84 \%$ of the maximum achievable vacuum (absolute zero in the pressure spectrum represents the value of $100 \%$ vacuum; but this can only be considered in the theoretical level).

It is therefore clear that in order to achieve a high level of vacuum, the corresponding pressure is required and increasing it brings two problems at the same time: the compressed air consumption increases (if we increase the inlet pressure on the ejector from $0.2 \mathrm{MPa}$ to 0.5 $\mathrm{MPa}$, the air consumption will increase by about $25 \mathrm{l}_{\mathrm{N}} / \mathrm{min}$, which means that for one working shift, i.e. 8 hours "unnecessarily" we consume compressed air worth about 400 EUR) and if we exceed the magic pressure limit of $0.6 \mathrm{MPa}$ stated by most manufacturers, the already mentioned "rupture" of the vacuum.

Therefore, it is more advantageous to solve the magnitude of the gripping force on the onesided gripping effector with active vacuum suction cups by the size of their total contact area with $\mathrm{O}_{\mathrm{M}}$ (suction cup size) than by disproportionately increasing the vacuum quality, Fig. 7.
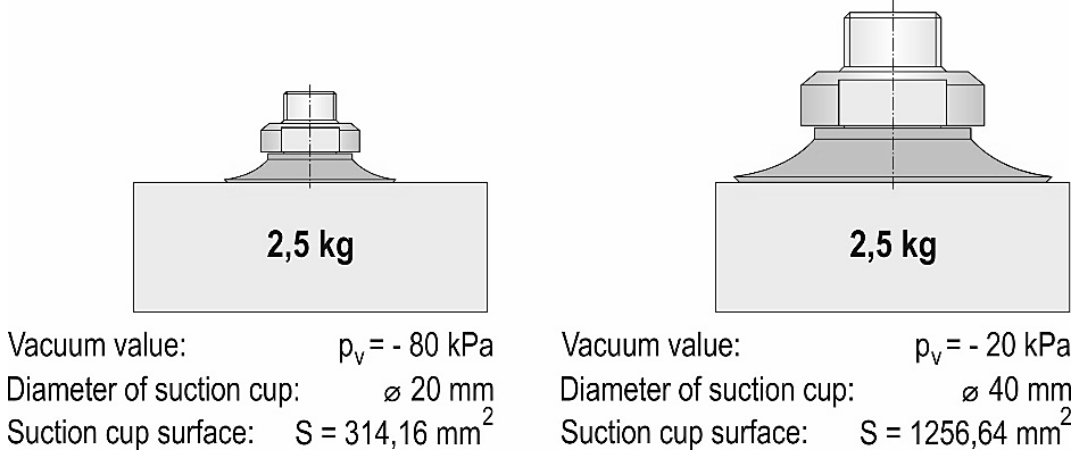

Fig. 7. Dependence of suction cup force ratios on vacuum quality and size of suction cup contact area with $O_{M}[5 ; 2]$

Thus, saving a vacuum actually means saving compressed air. This is all the more urgent when world statistics show that up to $75 \%$ of the world's total compressed air is used to blow surfaces and prepare vacuum in ejectors.

Methods of vacuum saving. The starting point is to determine the effective gripping force required for safe handling of OM. It already takes into account the dynamics of the movement of the manipulator (e.g. robot) [1]. In the calculations we use the value of the compressed air pressure in the circuit of max. $0.5 \mathrm{MPa}$. The choice of a suitable ejector then directly depends on the value of the required vacuum determined when calculating the size and number of suction cups [1]. Of course, the pressure level can be adjusted by optimization.

When choosing an ejector with the required vacuum quality, we often come across the fact that the quality and the required suction volume (ejector flow) are in contradiction with each other. If a high-quality vacuum is required, the ejector must have a small nozzle diameter, for 
volume we need this diameter as large as possible. As a result, it is not possible to achieve an optimal setting with a single-stage ejector. Therefore, it is necessary to choose either a two- or three-stage ejector, which will have a vacuum quality only slightly lower than a single-stage, the suction volume will increase (depending on the number of stages) by 40 to $250 \%$.

This has a huge effect on the conditions on the effector, as in order to gain the grip strength by increasing the diameter of the suction cup, the volume under its cuff will necessarily increase. If we are to create a perfect force connection of the suction cup with the object, we must "get rid" of the atmospheric air under the suction cup as quickly as possible. In addition, the volumes of hoses, couplings and other components of the vacuum circuit must be included in the total volume, fig. 8. All these volumes are taken into account in determining the required suction power of the ejector.

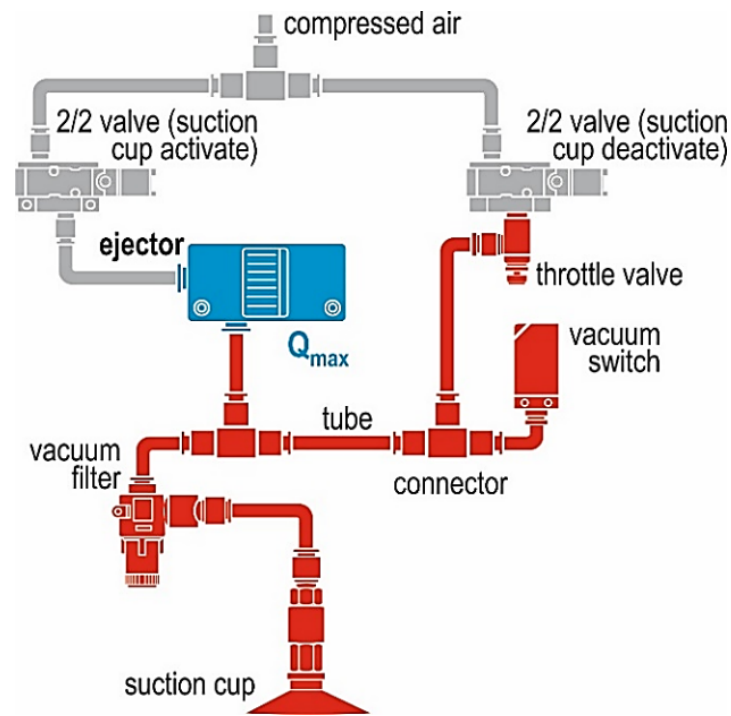

Fig. 8. Vacuum circuit volume balance [2]

Associated with this is the determination of the value of the so-called evacuation time $T_{1}$ and its multiples, Fig. 9.

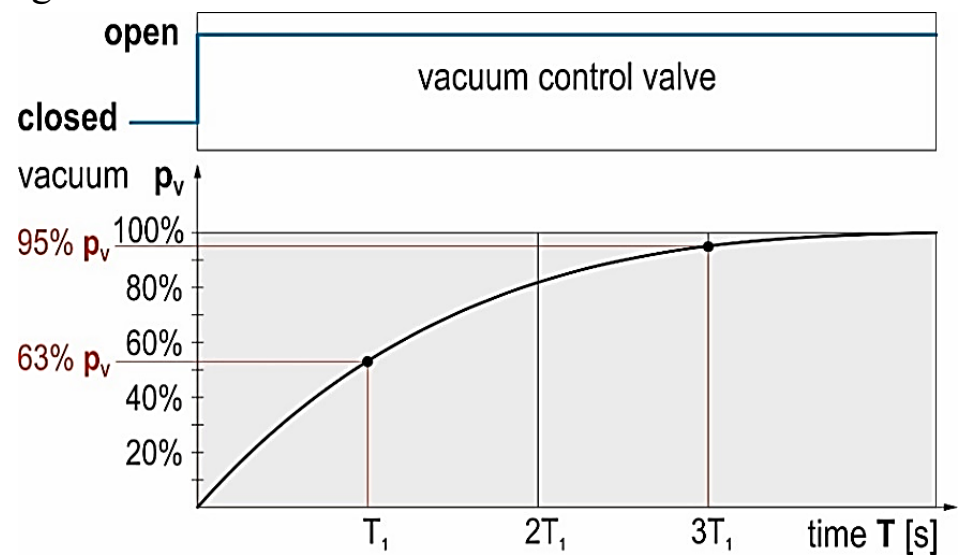

Fig. 9. Evacuation times of ejector

The vacuum in the ejector, if the circumstances of the handling task allow it, should not be developed throughout the handling task. To activate the vacuum under the suction cup, a short pulse of the compressed air stream is enough to generate a vacuum (of the order of 1-1.5 s), which will ensure that the suction cup adheres to the $\mathrm{O}_{M}$ surface, Fig. 10a).

Due to the non-return valve $1 \mathrm{SV} 01$ installed in the circuit, the vacuum under the suction cup is "locked" and its value is sufficient to keep the $\mathrm{O}_{M}$ in contact for the entire duration of the handling task, fig. 10b). To release the suction cup at the $\mathrm{O}_{M}$ storage location, it is sufficient to supply suitably throttled (throttle valve 1R01) compressed air for a short time (approx. $0.5 \mathrm{~s}$ ). 


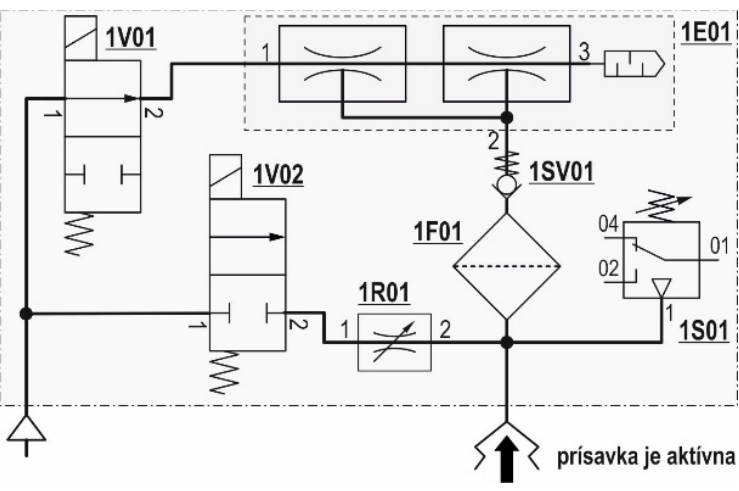

$a$

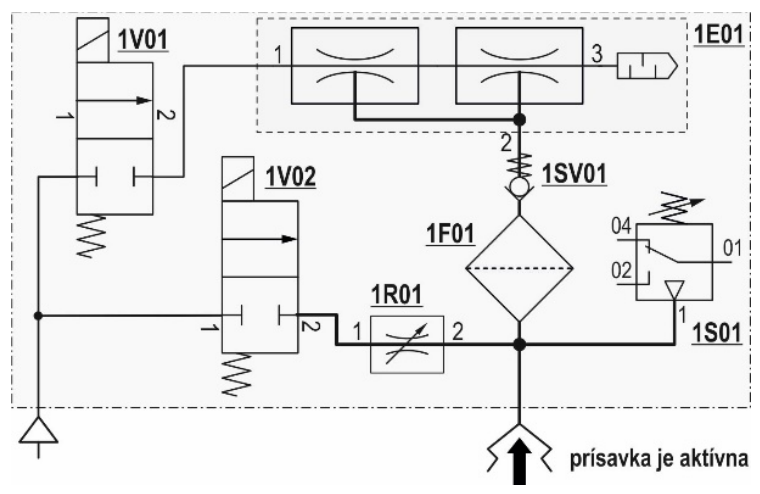

$b$

Fig. 10. Saving compressed air by arranging the circuit correctly

Conclusion. As shown in the article, the solution of air consumption as a large financial cost item in the operation of automated production is a current issue in the operation of the company. The basic premise of cost reduction is the rule: you save the most on what you don't have to produce. A suitable arrangement of the vacuum circuit for solving handling tasks with the use of gripping effectors with one-sided gripping (suction cups) is thus the most effective way to reduce operating costs just to implement such solutions.

Acknowledgment. This article was created thanks to the support of the KEGA project: 010TUKE-4/2020 Implementation of new knowledge and innovative approaches to the process of teaching robotics in the intentions of Industry 4.

This paper was published in cooperation with company KYBERNETES s.r.o. within the project "Research and development of the ECOGI product at KYBERNETES", ITMS Code of Project: $313012 Q 955$.

\section{References}

1. Hajduk, M., Tuleja, P.: Základy pneumatických mechanizmov I.: Výroba, úprava a rozvod stlačeného vzduchu a vákua, TU v Košiciach, Košice, 2013, ISBN 978-80-553-1605-5.

2. Hajduk M., Šidlovská L., Tuleja P.: Unilateral Gripping Mechanism Effectors, In: Applied Mechanics and Materials, Vol. 332 (july 2013), section OPTIROB 2013, Chapter 3: Robotics and Automation Systems, Control, pp. 181-185, Trans Tech Publications 2013, Switzerland, ISSN: 1662-7482.

3. Tuleja, P.: Design and realization of grippers with permanent magnets. Technical sciences and technologies: scientific journal / Chernihiv National University of Technology. - Chernihiv National University of Technology, 2019. - № 3 (17). - 314 p., pp 105-110, ISSN 2411-5363. Access method: https://tst.stu.cn.ua/articles/ 1578582029235.pdf.

4. https://www.smc.eu/sk-sk/produkty-a-podpora.

5. https://www.piab.com.

УДК (07)621.7,621.8

\section{Петер Тулея, Борис Джоббегі \\ ЗАДАЧА МАНІПУЛЯЦЇ̈, РЕАЛІЗОВАНА ЗА ДОПОМОГОЮ ВАКУУМНОЇ ПРИСОСКИ}

\footnotetext{
Актуальність теми досліджсення. У иій статті розглянуто як технічні, так $і$ економічні аспекти керування стисненим повітрям, яке є найбільш дорогим видом енергї, щуо використовується у виробничому секторі. Дуже важливо економити енергію як таку, не виключаючи і стиснене повітря.

Постановка проблеми. Мета статті - дати вичерпне уявлення про вирішення завдання одностороннього захоплення за допомогою вакууму. У роботі надано рекомендаџї щзодо їх вирішення з акцентом на шляхи для економії основної енергіі-стисненого повітря.

Аналіз останніх досліджень і публікацій. Нині ичій сфері приділяють велику увагу не тільки користувачі, цчо використовують стиснене повітря і вакуум, а й виробники техніки, щуо працюють із ними. Цим займаються практично всі великі виробники пневматичних компонентів.
} 
TECHNICAL SCIENCES AND TECHNOLOGIES

Виділення недосліджених частин загальної проблеми. У статті не приділяється увага виробництву й обробиі стисненого повітря, а тільки його витраті на отримання вакууму. Також у розрахунках вказуються тільки основні взаємозв 'язки, за якими досвідчений користувач знайде рімення своєї проблеми.

Постановка завдання. Мета статті - представити результати досліджень у иій області та вказати можливості технічних прочедур для вирішення проблеми застосування вакуумних захватних ефекторів із використанням активних вакуумних присосок.

Виклад основного матеріалу. Матеріал, який став основою статті, складається як із загальних знань, изо містяться в технічній літературі, так $і$ з власного аналізу часткових даних, узагальнених у висновках.

Висновки відповідно до статmі. У висновках, зроблених у статті, надано рекомендації для вирішення комплексу завдань із проєктування вакуумних захватних ефекторів із присосками.

Ключові слова: маніпуляція; маніпуляційне завдання; стиснене повітря; вакуум; присоска; пневматичний ланцюг. Рис.: 10. Табл.: 1. Бібл.: 5.

Tuleja Peter - Eng., PhD, assistant professor, Technical university in Kosice, Faculty of Mechanical Engineering, Institute of Automatization, Mechatronics, Robotics and Production Systems, Department of Production Systems and Robotics, Komenskeho Park 8, 04200 Kosice, Slovakia

E-mail: peter.tuleja@tuke.sk

Scopus Author ID: 55570858300

ORCID: https://orcid.org/0000-0001-6390-3109

Jobbagy Boris - Eng., PhD, KYBERNETES, s. r. o., Omska 14, 04001 Kosice, Slovakia

E-mail: boris.jobbagy@kybernetes.sk

ORCID: https://orcid.org/0000-0003-0491-0442

Tuleja, P., Jobbagy, B. (2020). Manipulation task realised by the vacuum suction cup implementation. Technical sciences and technologies, 4(22), pp. 48-56. 